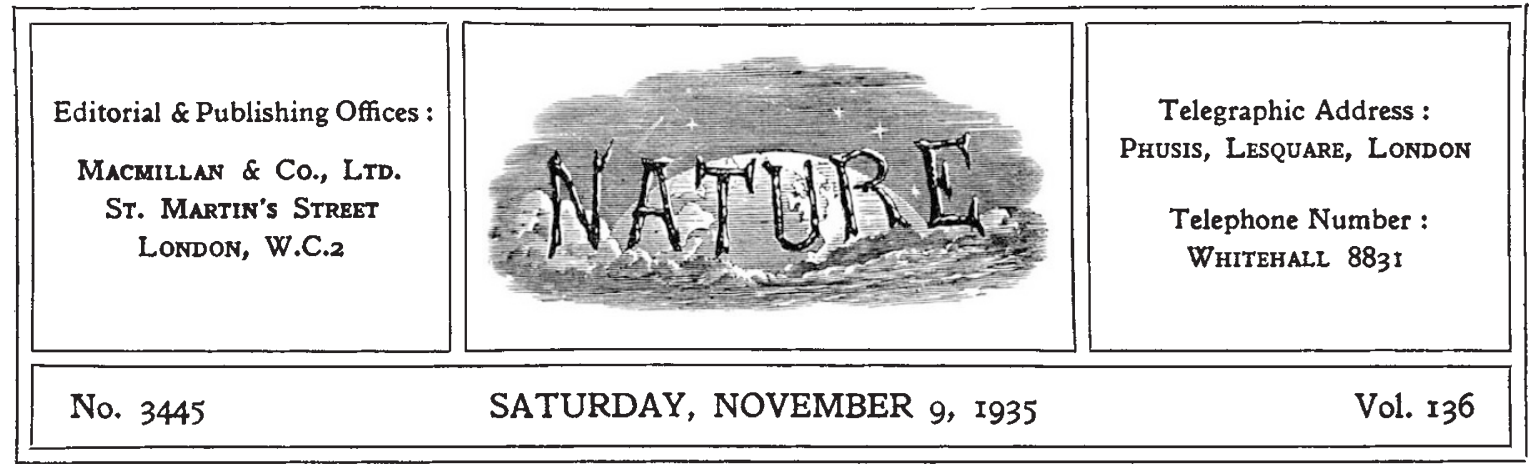

\title{
Science and Political Responsibility
}

$A^{s}$ these pages pass through the press and come to the hands of our readers, Great Britain once more lies under the stress of one of those periodically recurring emotional crises in which the future policy of government of the country for a period of greater or lesser duration is determined by popular vote. The gravity of the issues involved on this occasion needs no stress ; but it may well raise the question whether the machinery of democratic government is such as to adapt itself to that scientific approach to the solution of the problems of government and administration, which the course of events in the last ten or fifteen years has shown to be a necessity of this modern age. In the hundred years which have elapsed since the introduction of the Reform Bill, thanks in great measure to the British political genius for compromise, the ultimate control of the destinies of the nation has passed from what was virtually an oligarchy to the people as a whole without the more violent pangs which marked the birth of democracy in less fortunate conditions. No longer, however, is the electorate confronted with the relatively simple issues of 'party'. The problem of the future in an increasing degree must be the manner in which, and at what stage, the scientific and technical considerations, which it would seem must enter more and more largely into the shaping of public action, are to be brought home to democracy.

John Stuart Mill, with the characteristic optimism which underlay the logical exactitudes of the Philosophic Radicals, declared that the individual exercise of the franchise was to be preferred to all the advantages that might accrue from the most benevolent despotism; and the nineteenth century, also holding to the belief in the ultimate perfectibility of the individual through education, elected to follow him. The Great War struck the final blow at the barriers, comparatively few as they were, which still stood in the way of equality of status and opportunity for all. Of these the most formidable, perhaps, was the inequality of the position of women. By the irony of circumstances, however, that great upheaval also destroyed the conditions in which these opportunities were to come to fruition. The War revealed the enormous forces which it was possible to set in motion and direct to a given end by organisation, especially on a national basis, and the complexity of the problems arising from day to day, which could no longer be localised and isolated, but were liable to affect the whole world, even to its remotest parts, through the speeding up and improvement of communication and transport.

The optimism of the post.War period of reconstruction was short-lived. The stability of civilisation had suffered a shattering blow ; and throughout the world it was apparent that it was no longer possible to meet the issue by the traditional methods of party politics. The situation called for measures that were at once more drastic and more flexible, if the methods of science were to be applied to the problems of government. Action, when once a logical conclusion had been attained, was not a matter for further debate.

Even now it is too early to pass judgment on the means, some of them drastic, which have been adopted to cope with the crisis, and are still in some measure on their trial. The extended application of the results of scientific research in every field of production to meet human needs - this, too, has given rise to problems all its own-and the more highly organised methods of industry and commerce in the pursuit of efficiency and the 
elimination of waste, have led by analogy to the concept of the corporate State, highly organised on scientific lines as a unit, bringing with it the inevitable consequence of the institution of a dictator as a condition of success, whether that dictatorship were held by an individual, as in Italy and Germany, with limitations as in the United States of America, or more or less in commission as in the early stages of the National Government in Great Britain, or, in theory, in Russia.

The outcome, as is familiar to all, through the repercussion of economic and political factors, has been the intensive cultivation of the national spirit, to which concessions were made at the close of the War in the interests of justice and peace, but which has now become a source of irritation and danger greater than the injustices which it was fostered to remove. To the justification of political and economic exclusiveness has now been added the doctrine of race, with the implication of racial superiority and inferiority, which in Germany has been made the basis of internal policy to subserve the purpose of commercial and economic rivalry between Jew and Christian, and in the United States has served as an argument in favour of discriminatory laws regulating immigra. tion and imposing disabilities on certain classes of the population in social legislation.

If, however, exclusive nationalism claims to base itself upon a scientific racial theory, over against it must be set the movement towards internationalism, which has found material expression in the League of Nations. If, according to the one school, the nation is regarded as one stage in what is claimed to be a Darwinian struggle for existence, in the view of the other, it represents a phase from which we are said to be on the point of emerging in an evolution of the social organism in an ascending scale of complexity, which begins with the family, passes to the tribe and will culminate in some form of great commonwealth vast enough and elastic enough to embrace the whole of mankind.

If those who claim to speak with the authority of science may voice views so widely divergent, the puzzled layman may well ask where in all this controversy does science itself stand. Now science as such is not concerned with 'moral values', which in the long run determine the policy of the statesman, but with truth; and the man of science, as such and apart from his standing as a citizen, has no special claim to speak on the issues of political controversy, except in so far as his standing and the interests of his pursuits are affected as constituent elements of the community. When, however, the name and principles of science are invoked in support of political policy, it is to the interests of himself and of science in general-and indeed it is his duty-to examine and test the theories which have been invoked and their application, and to see not merely that they are correctly stated in accordance with the facts, but also that in their application they have not been distorted to fit the views of the partisan.

A lesson as to the true function of the man of science in relation to political controversy may perhaps be drawn from two recent publications dealing with the theories and practice of anthropological science. Of these one, "We Europeans" by Dr. Julian Huxley and Dr. A. C. Haddon, is the subject of notice in another column of this issue of NaTURE (see page 736), but it may be pointed out here that in this book the authors have effectually pricked the bubble of 'race' as applied in justification of the nationalism rampant in Europe to-day. They track down the 'Aryan Race' theory to its origin in a misinterpretationit might indeed be said a perversion-of ethnological theory, and finally cut away the ground from under 'racial' theory by demonstrating that, when examined in the light of modern methods and modern doctrines of genetic studies, race becomes virtually a meaningless expression.

In the second of these publications*-an excellent review by Mr. Penniman of the history of anthropological thought from its beginnings with the investigations of Herodotus down to the present day-the racial fallacy is traced to its origins in the writings of de Gobineau and others in the last century. It is instructive to note how, from the earliest times and long before anthropology had become an organised discipline, philosophers and political thinkers were drawing from the more or less systematic observations of travellers and historians the formularies upon which to base theories of the political and ethical ends of man.

At present, the trend of events is that the statesman must rely, in an increasing degree, on the findings of science in the interests of good government. If freedom and democracy are to endure, this constrains the man of science to hold a watching brief, lest the name of science be taken in vain and the power of the franchise abused in an uninstructed electorate.

* A Hundred Years of Anthropology. By T. K. Penniman. (Duckworth's 100 Years Series.) Pp. 400. (London: Gerald Duckworth and Co., Ltd., 1935.) 158. net. 